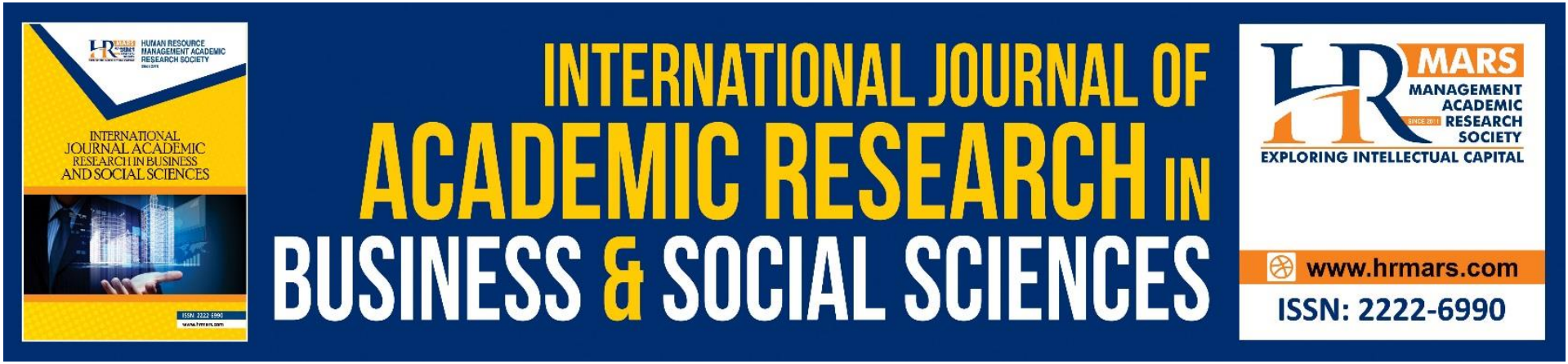

\title{
Measuring Successful Collaboration Project Between University and Industry in The Development Research Stages
}

Mohamad Faizal Ramli \& Aslan Amat Senin

To Link this Article: http://dx.doi.org/10.6007/IJARBSS/v11-i2/8400

DOI:10.6007/IJARBSS/v11-i2/8400

Received: 04 December 2020, Revised: 03 January 2021, Accepted: 15 January 2021

Published Online: 02 February 2021

In-Text Citation: (Ramli, \& Senin, 2021)

To Cite this Article: Ramli, M. F., \& Senin, A. A. (2021). Measuring Successful Collaboration Project Between University and Industry in The Development Research Stages. International Journal of Academic Research in Business and Social Sciences, 11(2), 42-53.

Copyright: @ 2021 The Author(s)

Published by Human Resource Management Academic Research Society (www.hrmars.com)

This article is published under the Creative Commons Attribution (CC BY 4.0) license. Anyone may reproduce, distribute, translate and create derivative works of this article (for both commercial and non-commercial purposes), subject to full attribution to the original publication and authors. The full terms of this license may be seen at: http://creativecommons.org/licences/by/4.0/legalcode

Vol. 11, No. 2, 2021, Pg. 42 - 53

Full Terms \& Conditions of access and use can be found at http://hrmars.com/index.php/pages/detail/publication-ethics 


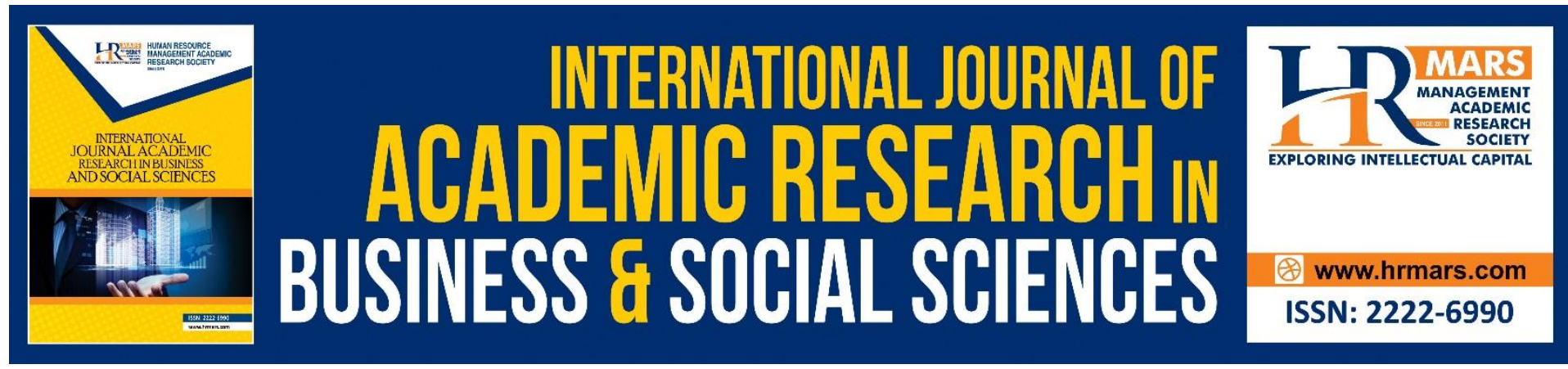

\title{
Measuring Successful Collaboration Project Between University and Industry in The Development Research Stages
}

\author{
Mohamad Faizal Ramli \& Aslan Amat Senin² \\ ${ }^{1}$ Faculty of Business and Management Universiti Teknologi MARA Cawangan Johor, \\ Kampus Segamat, Jalan Universiti Off Km. 1,2Jalan Muar 85000 Segamat Johor Darul Ta'zim, \\ MALAYSIA, ${ }^{2}$ Azman Hashim International Business School, Universiti Teknologi Malaysia, \\ 81310 Johor Bahru, Johor, Malaysia. \\ Email: faizalramli@uitm.edu.my, aslan@utm.my
}

\begin{abstract}
The collaboration between the university and the industry is beneficial to both parties. However, it is difficult to develop a successful collaboration due to the difference in research and organisation background from both sides. It is subjective to define the success of the collaboration, which can be based on the collaboration partner's objectives. Recently, some studies discuss the indicators to determine the success of a project, but there were limited studies that adapted this factor to measure the success of a research project. Thus, this study aims to measure the success of a collaboration project during the development research stages. The indicators of this study were process and outcome criteria to measure the success of a project. The respondents consist of 99 researchers who were involved in the project funded by a government grant scheme. In addition, 8 leaders were interviewed to measure the project's success. The results show that there was a significant difference between both partners on the process-related criteria. In conclusion, most of the projects were completed and each researcher has their own definition of success.
\end{abstract}

Keywords: University-Industry Collaboration, Success Criteria, Indicators, Research and Development, Performance Measurement

\section{Introduction}

University plays an important role as a source of innovation for companies (Rasiah \& Chandran, 2009). One of the effective ways to share and transfer knowledge between both institutions is through the collaboration project. In Malaysia, the collaboration between university and industry has emerged since the middle of the 1980s (Hamisah Tapsir et al., 2010). The collaboration is beneficial to both partners. Universities can enhance their financial support (Patil, 2012; Schuentze, 2001), academic results (Philbin, 2008; Dooley \& Kirk, 2007; Lee, Ohta, \& Kakehi, 2010) besides gaining more prestige and status (European Commission, 2007). Meanwhile, the industry collaborates with the university for the research and development (R\&D) activities to create innovation and become more competitive (Audretsch, Leyden, \& Link, 2012; Hanel \& St-Pierre, 2006; Okamuro, 2007). However, it is difficult to 
develop a successful collaboration (Dunowski et al., 2010), and the researchers need to improvise on their current practices for establishing a more effective collaboration. Besides, as stated by Seres et al. (2019), there was a lack of instrument or method to evaluate the performance or successful collaboration projects between the university and the industry. In Malaysia, some previous studies discussed the indicators to measure the successful collaboration project between the university and the industry (Abeda, Adnan, Saima, \& Aslan, 2011; Rast, Khabiri, \& Aslan, 2012; Chin, Spowage, \& Yap, 2011; Abeda, Adnan, Shazia, \& Aslan, 2015). These studies determined the success indicators, which mainly focused on the academics' perspectives. Currently, there is a lack of studies that adapted the indicators to determine the level of success among the university-industry collaboration project in Malaysia. Kuen et al. (2009) discussed the measurement of the successful collaboration project. The study revealed that $62.6 \%$ of the collaboration projects between the university and the industry in biotechnology, automotive, and electronics fields were completed. The result means that almost half of the collaboration projects had failed to be completed.

Based on the findings, the interviews were conducted on leaders who mentioned that there are a few projects that had failed to be completed, such as terminated projects during the collaboration and postponed projects. Besides, all of the respondents during the interview sessions mentioned the failure of commercialising the output products. Both partners have different perspectives or views in determining the success of a project. Thus, this study aims to determine the different perceptions between both researchers in defining the successful collaboration project during the development research stages. Besides that, it can provide an idea for future researchers or project management on determining the indicators to measure the success of a project. As explained by Seppo and Lilles (2012), the indicators were used to determine or evaluate the performance of researchers or projects. Both partners have their aims or objectives due to their different backgrounds. Thus, this study tries to answer two research questions. First, is the project collaboration successfully completed. Second, is there have different perspective of success between university and industry researchers. The result of this study explains whether there is a difference between both researchers in defining the success of the collaboration. Furthermore, this study explains the success or failure of the projects conducted by both parties.

\section{Literature Review}

Success can be defined based on the objectives stated by the collaboration stakeholders. The success indicators are different according to the objectives of the researchers (Witt, 1988). This statement is supported by Mora-Valentin, Montoro-Sanches and Guerras-Martin (2004) that the researchers' objectives can determine the success of a collaboration project. In the university-industry collaboration project, each type of collaboration has different objectives and outputs; thus, it is difficult to determine the indicators or tools to measure collaboration projects (Perkmann, Neely, \& Walsh, 2011).

Rast et al. (2012) discussed the academics' perspectives regarding the indicators that should be used to measure the success of collaboration projects. The study stated that there are some indicators in the collaboration through contract research preferred by academicians to measure their projects, such as the amount of income, product, and publication. Besides, Abeda et al. (2011) also discussed the academics' perspectives. The study developed the CASEM Model to determine the important indicators for successful collaboration projects. The model determines different criteria for each evaluation matrix. In the joint venture 
project, some of the indicators that can be used in measuring the project performance are the number of projects, staff, researchers, and publications.

Perkmann et al. (2011) introduced a success map, which consisted of several indicators to measure successful projects. According to the study, each stage should have its indicators to measure success. They divided the indicators based on four main stages, such as input, process, output, and impacts. Figure 1 presents the details of the indicators.

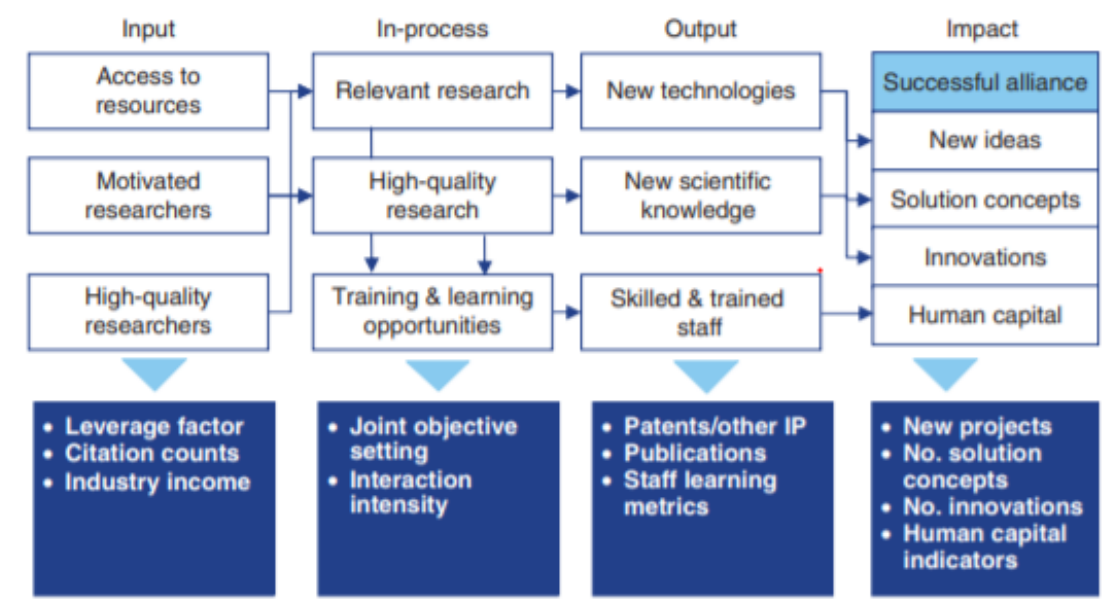

Figure 1: Success map to measure the successful project (Perkmann et al., 2011)

In addition, the stages introduced by Perkmann et al. (2011) were adopted by Frenandes et al. (2017) based on R\&D collaboration between the university and the industry. The success indicators consist of both tangible and intangible indicators. Some indicators used by them to measure R\&D collaboration projects are the researcher's motivation and capabilities, number of publications, patent, new product, process improvement, solution for the problem, number of postgraduates, and income generation. The output products during each stage can be used as indicators to measure the projects' performance.

Studies conducted by Seppo and Lilles (2012) and Seres et al. (2019) were based on the success indicators for different types of collaboration. The studies divided the indicators into three stages, such as input, output, and impacts. For the R\&D collaboration project, the indicators that can be used are financial allocation, motivation, and capabilities of both institutions, the number of publications, consultation, invention, new process, and products. Besides, the output from the collaboration can determine the important indicators to measure successful collaborations. Seres et al. (2019) divided the impacts into two indicators, namely economic and social impacts. Some important indicators in economic impacts are income generation, company competitiveness, productivity, and the number of new collaborations among researchers. Social impacts refer to the effects on the quality of life, health, pollution, energy used, and other indicators.

A study by Nelson (2005) on a firm's project collaboration had determined two important criteria to measure successful projects. The study divided the criteria into process and outcome. According to the study, a project is considered successful when it produces a product within the deadline and budget allocation besides fulfilling the quality and specification, which can lead to acceptance by target customers. 
The indicators in this study measured successful collaborations through two dimensions as suggested by Nelson (2005). The project is considered successful when it produces quality products according to the deadline and budget allocation.

\section{Research Methodology}

This study distributed the survey questionnaires to 170 respondents who were involved in the project funded by government fund. The fund is to encourage the collaboration between the industry and the public research institution in Malaysia and produce quality products for commercialisation. The questionnaires were distributed by email, face-to-face, and postage to leaders and co-researchers. The instrument measured variables on a Likert-Scale of 5 points, from strongly disagree to strongly agree. The operationalization of the variables and the questionnaires in this study as shown in Table 1.

Table 1

The Sources of Variables in This Study

\begin{tabular}{lll} 
No & Variable (success criteria) & Sources \\
\hline 1) & Process related criteria & Dunowski et al.(2010), Nelson (2005), \\
& & $\begin{array}{l}\text { Atkinson (1999), Shenhar, Dvir, Levy, \& } \\
\text { Maltz (2001) }\end{array}$ \\
\cline { 2 - 3 } 2) & Outcome related criteria & $\begin{array}{l}\text { Nelson (2005), Shenhar et al. (2001), Chin } \\
\text { et al. (2011), Permman et al. (2011) }\end{array}$
\end{tabular}

However, only 99 feedbacks were received, and they were analysed using descriptive and ttest analyses to measure the researchers' views on the collaboration's success. In this study, the success criteria variables consist of 7 items, thus the number of respondents required is 35 (7x5). In this study, total respondents were 99 researchers, thus it met the assumption based on the rule of thumb discussed by Hair et al. (2006). Besides, Roscoe (1975) indicated that the sample size consists of more than 30 respondents is acceptable for conducting a research. The SPSS software was used to analyse the quantitative data. In addition, eight semi-structured interviews on the leaders were conducted to provide more detailed explanations and supports for the results. For interviews result, content analysis was used to analyse the result.

\section{Result}

\section{Demographics of Respondents}

Table 2 showed the demographic details of respondents involved in this study. The respondents consist of $84.9 \%$ Malay, $12.1 \%$ Chinese and $3 \%$ were Indian and others races. Besides, $67.7 \%$ were male researchers and $32.3 \%$ were female researchers. The highest percentage of respondents came from the age between 41 to 50 years old while only 2 respondents were recorded above 60 years old. In this study, the co-researchers represent $61.6 \%$ of total respondents while R\&D project leaders were $38.4 \%$. The results also indicated that 32.3\% respondents had 11-20 years of working experience, followed by 6 to 10 years $(26.3 \%)$ and only $5.1 \%$ had more than 30 years of working experience. Finally, all of the respondents involved in this study mentioned that they had experiences involved in collaboration projects, particularly during the development research stage. 
Table 2

Demographic Statistics $(N=99)$

\begin{tabular}{|c|c|c|c|}
\hline & Demography & Frequency & Percentage \\
\hline \multirow[t]{4}{*}{ Ethnic } & Malay & 84 & 84.9 \\
\hline & Chinese & 12 & 12.10 \\
\hline & Indian & 2 & 2.00 \\
\hline & Others & 1 & 1.00 \\
\hline \multirow[t]{2}{*}{ Gender } & Male & 67 & 67.70 \\
\hline & Female & 32 & 32.30 \\
\hline \multirow[t]{5}{*}{ Age } & Below 30 years old & 14 & 14.10 \\
\hline & $31-40$ years old & 29 & 29.30 \\
\hline & $41-50$ years old & 37 & 37.40 \\
\hline & $51-60$ years old & 17 & 17.20 \\
\hline & Above 60 years old & 2 & 2.00 \\
\hline \multirow[t]{2}{*}{ Position } & R\&D project leader & 38 & 38.40 \\
\hline & Co-researcher & 61 & 61.60 \\
\hline \multirow[t]{5}{*}{ Working experience } & $1-5$ years & 14 & 14.10 \\
\hline & $6-10$ years & 26 & 26.3 \\
\hline & $11-20$ years & 32 & 32.3 \\
\hline & $21-30$ years & 22 & 22.2 \\
\hline & More than 30 years & 5 & 5.10 \\
\hline $\begin{array}{l}\text { Experience involved in } \\
\text { collaboration during } \\
\text { development research } \\
\text { stage }\end{array}$ & Yes & 99 & 100 \\
\hline
\end{tabular}

\section{Reliability Assessment}

The reliability of the measurement items for all the variables are as indicated in Table 3 . The result showed that all variables received the Cronbach coefficient alpha more than 0.60 . The Cronbach coefficient alpha for process related criteria $(0.795)$ and outcome related criteria (0.935), it was considered as adequate and good (Gibson, 2016). Thus, it explained that the research instrument is reliable to the context of study. 
Table 3

Reliability Test of the Success Criteria

\begin{tabular}{lcc}
\hline & No of items & Cronbach's Alpha \\
\hline Success criteria & & \\
\hline Process related criteria & 2 items & 0.795 \\
Outcome related criteria & 5 items & 0.935
\end{tabular}

Based on the results, the industry researchers believed that the project was successful in "producing products for the target markets" (mean score: 4.02), followed by "achieving the product specification" (3.94), and "produce high-quality products" (3.92). The least successful indicator achieved by the researchers was "completing the project on time". Compared to the university's perspectives, they agreed that the collaboration project was a success in terms of "using the financial allocation" (4.19), whereas the least successful indicators were "produce high quality" and "produce product that lead to commercialisation" (3.88). The result concluded that both partners have their expectations or perspectives on the collaboration's success.

In addition, 66.7 to $76.8 \%$ of the respondents agreed that the collaboration projects were completed, and only a few respondents mentioned that the collaboration project failed to be completed. Eleven per cent of the respondents disagreed that "the collaboration projects were completed according to the deadline" and $5 \%$ of them disagreed on "the collaboration project produces products that lead to commercialisation".

Table 4

Mean Analysis on Measuring the Success of the University-Industry Collaboration in the Development Research Stages

\begin{tabular}{lccc}
\hline Success indicators & Researchers & N & Mean \\
\hline The collaboration project produces and creates & University & 48 & 3.88 \\
\cline { 2 - 4 } high-quality products & Industry & 51 & 3.92 \\
\hline The collaboration project achieves the products' & University & 48 & 4.06 \\
\cline { 2 - 4 } specification and performance & Industry & 51 & 3.94 \\
\hline The collaboration project produces products that & University & 48 & 3.94 \\
\cline { 2 - 4 } help to solve firm problems & Industry & 51 & 3.78 \\
\hline The collaboration project produces products that & University & 48 & 3.88 \\
\cline { 2 - 4 } lead to commercialisation & Industry & 51 & 3.84 \\
\hline The collaboration project produces products that & University & 48 & 4.08 \\
\cline { 2 - 4 } are required by the target markets & Industry & 51 & 4.02 \\
\hline The collaboration project is completed on time & University & 48 & 3.92 \\
\cline { 2 - 4 } & Industry & 51 & 3.59 \\
\hline The collaboration project uses the budget allocated & University & 48 & 4.19 \\
\cline { 2 - 4 } & Industry & 51 & 3.82 \\
\hline
\end{tabular}


INTERNATIONAL JOURNAL OF ACADEMIC RESEARCH IN BUSINESS AND SOCIAL SCIENCES Vol. 11, No. 2, 2021, E-ISSN: 2222-6990 @ 2021 HRMARS

Table 5

T-Test Analysis on Measuring the Success of the University-Industry Collaboration in the Development Research Stages

Independent Sample Test (by Factors)

\begin{tabular}{|c|c|c|c|c|c|}
\hline \multirow[t]{2}{*}{ Success indicators } & & \multicolumn{2}{|c|}{$\begin{array}{c}\text { Levene's Test for } \\
\text { equality of variances }\end{array}$} & \multirow[t]{2}{*}{$T$-test } & \multirow[t]{2}{*}{$\begin{array}{c}\text { Sig } \\
\text { (2- tailed) }\end{array}$} \\
\hline & & $F$ & Sig & & \\
\hline \multirow[t]{2}{*}{ Process-related criteria } & $\begin{array}{l}\text { Equal variances } \\
\text { assumed }\end{array}$ & .736 & .393 & 2.242 & $.027 *$ \\
\hline & $\begin{array}{l}\text { Equal variance } \\
\text { not assumed }\end{array}$ & & & 2.246 & .027 \\
\hline \multirow[t]{2}{*}{ Outcome-related criteria } & $\begin{array}{l}\text { Equal variances } \\
\text { assumed }\end{array}$ & 2.335 & .130 & .432 & .667 \\
\hline & $\begin{array}{l}\text { Equal variance } \\
\text { not assumed }\end{array}$ & & & .435 & .664 \\
\hline
\end{tabular}

*Significant at $p<0.05$

Independent Sample Test (by Items)

\begin{tabular}{|c|c|c|c|c|}
\hline \multirow[t]{2}{*}{ Success indicators } & \multicolumn{2}{|c|}{$\begin{array}{l}\text { Levene's Test for } \\
\text { equality of variances }\end{array}$} & \multirow[t]{2}{*}{$T$-test } & \multirow[t]{2}{*}{$\begin{array}{c}\text { Sig } \\
\text { (2- tailed) }\end{array}$} \\
\hline & $F$ & Sig & & \\
\hline $\begin{array}{l}\text { The collaboration project produces and } \\
\text { creates high-quality products }\end{array}$ & .545 & .462 & -.271 & .787 \\
\hline $\begin{array}{l}\text { The collaboration project achieves the } \\
\text { product specification and performance }\end{array}$ & .227 & .635 & .769 & .444 \\
\hline $\begin{array}{l}\text { The collaboration project produces } \\
\text { products that help to solve firm problems }\end{array}$ & 3.846 & .053 & .900 & .370 \\
\hline $\begin{array}{l}\text { The collaboration project produces } \\
\text { products that lead to commercialisation }\end{array}$ & .539 & .465 & .172 & .864 \\
\hline $\begin{array}{l}\text { The collaboration project produces } \\
\text { products that are required by the target } \\
\text { markets }\end{array}$ & 2.364 & .127 & .408 & .685 \\
\hline $\begin{array}{l}\text { The collaboration project is completed } \\
\text { on time }\end{array}$ & .596 & .442 & 1.714 & .090 \\
\hline $\begin{array}{l}\text { The collaboration project uses the } \\
\text { budget allocated }\end{array}$ & .785 & .378 & 2.455 & $.016^{*}$ \\
\hline
\end{tabular}

*Significant at $p<0.05$

The result in Table 5 explains that the process-related criteria had a significant difference between both collaboration partners. The significant result equals to 0.027 , which is less than 0.05. To determine the success of a project, both partners have different perspectives on this criterion. In addition, the independent sample $t$-test table shows that only "the collaboration project uses the budget allocated" had a significant difference $(s i g=0.016)$ and other items were recorded as not significant. 


\section{Discussion}

The analysis on each item shows that only "the collaboration project uses the budget allocated" had a significant difference between them. It is believed that university researchers tend to determine the success of their project collaboration based on budget allocation than industry researchers. For the industry, they use their own money in some cases to support the collaboration due to the limited amount of money approved by the government. It means that universities depend on budget allocation. During the interview, this statement was agreed by leaders who mentioned that industries also spend their money on some additional expenses that are not covered by the fund.

For the industry researchers, their collaboration projects have more success on products required by the target markets. This statement is in line with the main objective of the industry, which is to produce competitive products that meet the market requirements to gain profits. Previous studies mentioned that the main objective of the industry is to develop competitive products (Rohrbeck \& Arnold, 2006; Abeda et al., 2011; Zaky \& Faham, 2004; Hamisah Tapsir et al., 2010). Shenhar et al. (2001) stated that when a product is purchased and used by customers besides fulfilling their need and requirement, the project can be considered as a success. This statement is similar to Nelson (2005) who mentioned that the project's success is based on the production of quality products within the deadline that fulfilled the target market's expectation. Interview sessions confirmed that this factor was important for leaders to measure a successful collaboration. The production of products that fulfilled consumers' expectations can provide advantages to gain more profits and become more competitive.

Based on the results, a few projects failed to achieve the level of success. The results of the mean analysis show that all respondents indicated high acceptance on all levels of success; however, industry researchers moderately accepted that "the collaboration project is completed on time". They might have faced problems during collaboration, such as issues regarding university researchers' time constraint, delay of payment, and IP issues that led to the extension of projects; hence, causing a delay in completing a project according to the time frame. As outlined in the interview sessions, time was indicated as an important indicator for industry researchers instead of product development to measure the success of a research project. It is believed that time is money for industry researchers where they need to develop a project according to the time frame to achieve a competitive market and compete with competitors. This situation contradicted with university researchers where all the leaders did not mention about time as an indicator to measure a successful research project during the development research stage.

This statement is consistent with the nature of research activities, which is more relaxed, treated as part-time activities (Zaki \& Faham, 2004; Hamisah Tapsir et al., 2010), and taking more time to be completed compared to the industry (Bruneel, D'Este, \& Salter, 2010; Salter, Bruneel, \& D'este, 2009). This situation might be due to the time issue faced by researchers who are involved in the collaboration project funded by the government or university. It is common for the university to take more time to produce findings or complete a project. This culture is however different from the industry's requirements or objectives. Previous studies mentioned that industry research is conducted in a short duration to gain competitive advantages and profits. Dunowski et al. (2010) stated that the company uses time, cost, and quality as indicators in measuring the success of a project with the university. Thus, both institutions need to understand their partners' requirements to collaborate effectively. 


\section{Conclusion}

The respondents provided high mean values on the listed success indicators. Although a few projects failed to be completed, most of the projects were completed. The researchers have different perspectives on the collaboration's success. Each partner should clearly define their objectives to ensure that both partner's motives can be achieved in the collaboration. The information from both partners helped this study to educate future researchers on the different views among researchers, and they can use the findings as a guideline to provide an in-depth understanding of the partners. This strategy can develop a more successful collaboration in the future.

This study contributes to the body of the knowledge in the field of university-industry R\&D collaboration in Malaysia. It reduces the gaps of knowledge regarding collaboration particularly during development research stage. The results of this study can increase the partners' understanding about the requirement set by each other. Based on the level of success defined in this study, the researchers can educate about the collaboration stakeholders' perception on success and increase their understanding on the level of success in university-industry collaboration in this country.

\section{Acknowledgements}

This work was supported by Ministry of Higher Education, Malaysia (Grant No: FRGS R.J130000.7829.4F927)

\section{References}

Abeda, M. I., Adnan, S. K., Saima, I., \& Aslan, A. S. (2011). Designing of success criteria-based evaluation model for assessing the research collaboration between university and industry. International Journal of Business Research and Management, 2(2), pp. 5973.

Abeda, M. I., Shahid, A. K., Shazia, P., \& Aslan, A. S. (2015). An efficient evaluation model for the assessment of university-industry research collaboration in Malaysia. Research Journal of Applied Sciences, Engineering and Technology, 10(3), pp. 298-306.

Atkinson, R. (1999). Project management: cost, time and quality, two best guesses and a phenomenon, it's time to accept other success criteria. International Journal of Project Management, 17(6), pp. 337-342.

Audretsch, D. A., Leyden, D. P., \& Link, A. N. (2012). Universities as research partners in publicly supported entrepreneurial firms. This paper was prepared for presentation at the Workshop on Academic Entrepreneurship and Economic Competitiveness, Basque Institute of Competitiveness, San Sebastian, Spain. September 8-9, 2011. Revised, January 1, 2012.

Bruneel, J., D'Este, P., \& Salter, A. (2010). Investigating the factors that diminish the barriers to university-industry collaboration. Research Policy, 39 (2010) pp. 858-868.

Chin, C. M. M., Spowage, A., \& Yap, E. H. (2011). Development of a project management methodology for use in a university-industry collaborative research environment. Proceedings of The 10th European Conference On Research Methodology For Business And Management Studies, 125-132.

Dooley, L., \& Kirk, D. (2007). University-industry collaboration grafting the entrepreneurial paradigm onto academic structures. European Journal of Innovation Management, 10 (3), pp. 316-332. 
Dunowski, J. P., Schultz, C., Kock, A., Gemunden, H. G., \& Salomo, S. (2010). Implementing university collaboration strategies through portfolio management. Paper to be presented at the Summer Conference 2010 On "Opening Up Innovation: Strategy, Organization and Technology" at Imperial College London Business School, June 16 18, 2010.

European Commission: Commission Of the European Communities. (2007), Accompanying document to the communication from the commission to the council, the European parliament, the European economic and social committee and the committee of the regions: improving knowledge transfer between research institutions and industry across Europe: embracing open innovation- Implementing the Lisbon agenda Voluntary guidelines for universities and other research institutions to improve their links with industry across Europe. Brussels, 4.4.2007 SEC (2007) 449.

Fernandes, G., Pinto, B. B., Araújo, B., Magalhães, P., \& Machado, R. J. (2017). A Method for Measuring the Success of Collaborative University- Industry R\&D Funded Contract. Procedia Computer Science 121 (2017) 451-460.

Gibson, T., Kerr, D., \& Fisher, R. (2016). Accelerating supply chain management learning: identifying enablers from a university-industry collaboration. Supply Chain Management, 21(4), pp. 470-484.

Hair, J.F, W.C. Black, B.J. Babin, R.E. Anderson, \& R.I. Tatham. (2006). Multivariate data analysis. (6th ed.) Pearson: Prentice Hall.

Hamisah, T., Aieni, N. M., Fauzi, A. I., Abdul Karim, M., Suhaila, M. S., \& Fazilah, A. M. (2010). University-industry partnerships: fostering strategic linkages at institutions of higher learning in Malaysia, UTM Press.

Hanel, P., \& St-Pierre, M. (2006). Industry-university collaboration by Canadian manufacturing firms. Journal of Technology Transfer, 31, pp.485-499.

Keun, L., Joseph, K. J., Abraham, V., Jong-Hak, E., Guisheng, W., Yi, W., Rasiah, R., Chandran, G. V. R., Intarakumnerd, P., Schiller, D., Hyun-Dae, C., Boo-Young E., \& Raeyoon, K. (2009). Promoting Effective Modes of University-Industry Interaction and their Evolution for Economic Catch-up in Asia. Final technical report.

Lee, K-J., Ohta, T., \& Kakehi, K. (2010). Formal boundary spanning by industry liaison offices and the changing pattern of university-industry cooperative research: the case of the University OfTokyo. Technology Analysis \& Strategic Management, 22 (2),pp. 189206.

Mora-Valentin, E. M., Montoro-Sanches, A., \& Guerras-Martin, L. A. (2004). Determining factors in the success of $R \& D$ cooperative agreements between firms and research organizations. Research Policy, 33(1), pp.17-40.

Nelson, R. R. (2005). Project retrospectives: Evaluating project success, failure, and everything in between, MIS Quarterly Executive, Vol. 4 No. 3.

Okamuro, H. (2007). Determinants of successful R\&D cooperation in Japanese small business: the impact of organizational and contractual characteristics. Research Policy, 36(10), 1529-1544

Patil, R. R. (2012). Academia-industry collaboration is not necessarily a conflict of interest in the context of public health education and research. Universal Journal of Education and General Studies, 1(2), pp. 028-032.

Perkmann, M., Neely, A., \& Walsh, K. (2011). How should firms evaluate success in universityindustry alliances? A performance measurement system. R\&D Management ,41, 2, 2011. 
Philbin, S. P. (2008). Process model for university-industry research collaboration. European Journal of Innovation Management, 11(4), pp. 488-521.

Rasiah, R., \& Chandran, V. G. R. (2009). University-industry R\&D collaboration in the automotive, biotechnology and electronics firms in Malaysia. The paper is a first draft submitted for consideration for presentation at the 7th Globelics Conference organized by UNU-MERIT, Dakar, 6-8 October 2009.

Rast, S., Khabiri, N., \& Aslan, A. S. (2012). Evaluation framework for assessing universityindustry collaborative research and technological initiative, Procedia - Social and Behavioral Sciences, 40 (2012),pp. 410 - 416.

Rohrbeck, R., \& Arnold, H. M. (2006). Making university-industry collaboration work - a case study on the Deutsche Telekom laboratories contrasted with findings in literature. ISPIM Annual Conference: "Networks for Innovation"; 2006; Athens, Greece pg.11.

Roscoe, J. T. (1975). Fundamental Research Statistics for the Behavioural Sciences, 2nd edition. New York: Holt Rinehart \& Winston.

Salter, A., Bruneel, J., \& D'este, P. (2009). Investigating the factors that diminish the barriers to university-industry collaboration. paper to be presented at the Summer Conference 2009 on CBS - Copenhagen Business School.

Schuetze, H. G. (2001). Issues of organization and management of knowledge transfer between universities and industry in North America, Europe and Japan. OECD/Japanese High-level Forum on Managing University/Industry Relationships: The Role of Knowledge Management.

Seppo, M., \& Alo, L. (2012). Indicators measuring university-industry cooperation. Discussions on Estonian Economic Policy, Vol. 20, Issue 1, p. 204, January 2012, Available at SSRN: https://ssrn.com/abstract=2194394.

Seres, L., Pavlicevic, V., Tumbas,P., Matkovic, P., \& Maric, M. (2019). A performance indicators of university-industry collaboration, Proceedings of EDULEARN19 Conference 1st-3rd July 2019, Palma, Mallorca, Spain, ISBN: 978-84-09-12031-4.

Shenhar A. J., Dvir, D., Levy, O., \& Maltz, A. (2001). Project success: A multidimensional strategic concept. Long Range Planning, 34 (2001), pp. 699-725.

Wit, A. D. (1998). Measurement of project success. Project Management, Vol 6 No 3 August 1988.

Zaky, A. A., \& Faham, M. M. (2004). The university-industry gap and its effect on research and development in developing countries. Arab Academy for Science and Technology Egypt. 